\title{
The Influence of the Foreign Companies in Developing the Technological Absorption Capacity of the Romanian Economy During the Current Financial Crisis
}

\author{
Constantinescu Lucretia Mariana, Cucui Ion, Cucui Floriana Andra, Goldbach Ioana Raluca \\ University Valahia of Targoviste, Targoviste, Romania
}

\begin{abstract}
Creating companies abroad, in ex-socialist countries of Central and Eastern Europe, has experienced a strong progression, following the amplification process of globalization of world markets, intensification of international trade and technological development. We are witnessing a regional disparity regarding the volume of foreign investments in this area, which is due to the difference of attractiveness of host countries economy. The attractiveness of these economies is conditioned, in its turn, by the importance of economic factors and the quality of existing infrastructures, which is at their turn facing an increasing complexity of technology. Business relocation of foreign investors is influenced also by the institutional environment, because foreign investors hope to capitalize on the collateral effects offered by the investment environment in the host country, such as research laboratories and existing infrastructure, without neglecting the benefits of a highly qualified workforce at reduced costs, some geopolitical advantages, etc.. After EU accession, the attractiveness index of business environment in Romania has increased from (-59\%) in 2005 to $66 \%$ (2008), and Romania was considered among the most attractive economies in Central and Eastern Europe, along with Russia where the attractiveness index increased from $63 \%$ (2007) to $72 \%$ (2008) and Ukraine which has seen an increase in the attractiveness index of the business environment from 56\% (2007) to 67\% (2008). This paper aims to highlight the positive effects induced by international business companies in assessing technological absorption capacity of the Romanian economy and to provide economic analysis of the "cause-effect" link between the attractiveness of the Romanian economy-governance - the intake of foreign investment straight to the active processing export of Romania under the impact of the overall effects of international financial crisis.
\end{abstract}

Keywords: direct foreign investment, Romanian economy attractiveness, competitiveness, governance, foreign trade

\section{Introduction}

Mid-1990s was marked by the process of internationalization of business, and the number of companies seeking expansion into foreign markets is increasing every year.

Constantinescu Lucretia Mariana, Ph.D. assistant, Management-Marketing Department, University Valahia of Targoviste. Cucui Ion, Ph.D., Accounting-Finances Department, University Valahia of Targoviste.

Cucui Floriana Andra, Ph.D. candidate, University Valahia of Targoviste.

Goldbach Ioana Raluca, Ph.D. candidate, University Valahia of Targoviste. 
Typology of strategies to penetrate foreign markets for a company is determined by the complexity of the international space approach and the concerted action of four factors (Dumitru, 2005, p. 183):

- Size of effort allocated to the internationalization process by the company;

- Intensity of penetration risk of foreign markets;

- Keeping control of business by foreign investors on the reference market;

- Size of the expected profit to be obtained as a result of processing the penetrated foreign market.

The way in which the company makes a sound balance "commitment-risk/control-profit" and chooses one of the many ways of implementation of the multi-country strategy only to prove the skills which give the investing company the possibility to achieve its objectives (see Figure 1).

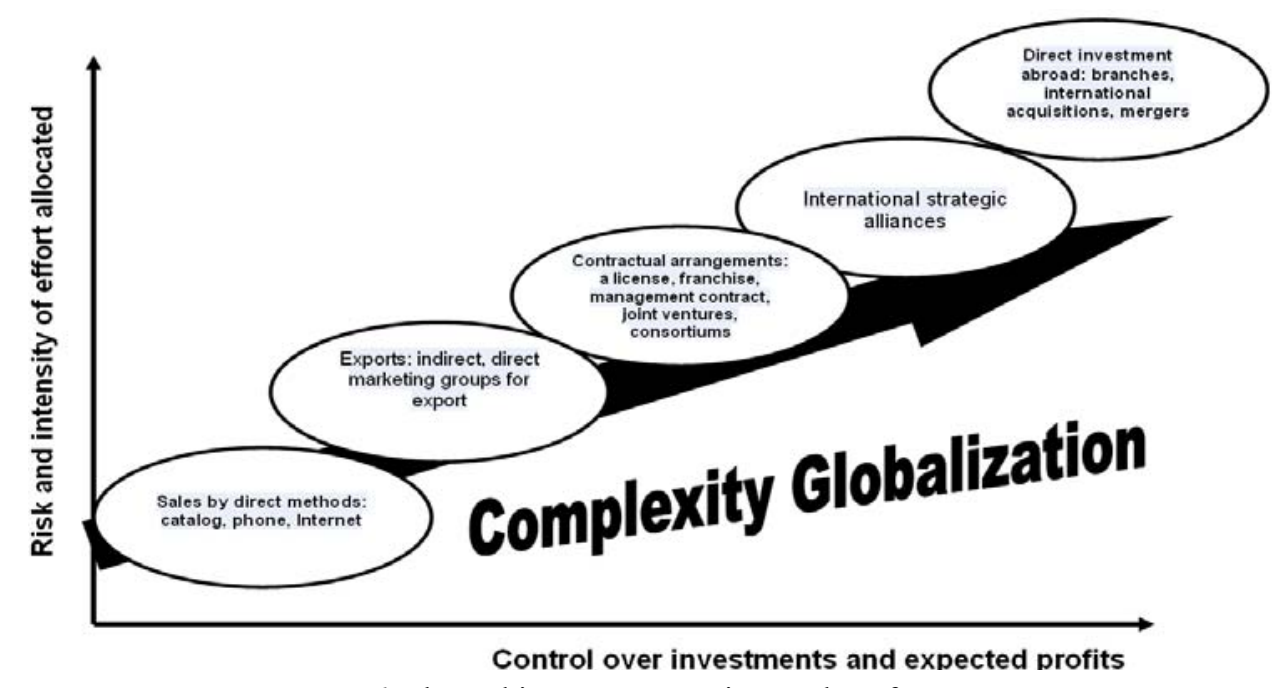

Figure 1. The multi-country strategies typology for a company.

According to John Dunning's eclectic theory, foreign direct investment (FDI) is a complex phenomenon which can be explained by an "accumulation of motives" aiming at specific benefits for the host country, specific advantages for the owner of the investing company and its ability to internalize these benefits. FDI is the most complex path of development and entry on the foreign markets which companies operating in foreign markets turn to, due to the following reasons:

- A search for resources;

- A search of markets;

- Desired efficiency;

- A search of strategic assets: favourable opportunities provided in exchange for the localized tactical knowledge (Voinea, 2007, p. 54).

\section{Problem Formulation}

FDI is the most volatile component of GDP, when the exports of goods/services go through a recession and the decline is usually due to decreases in investment spending.

Although much less volatile than domestic investment, FDI respondes to far more determiners than the national ones. Romania accession to European Union (from Juanary 1, 2007), along with Western European 
countries, driven by strategic interests of both parties, requires the expansion of international cooperation with all world states and especially with those developed, as well as, an acceleration to attract investments. Access to markets is crucial for foreign investors, even for the strategic ones, aiming at long term objectives regarding expansion of the market of products/services offered by them, as well as, the construction of some distribution networks with clear synergistic effect for them. No low cost benefits of the countries receiving FDI is insignificant and some investors see in this an essential component of their own multi-country strategies for developing of their companies. Also, in equal measure of interest, it is the low cost of labour force and that of material resources when they are particularly attractive. We should not be overlook the fact, that most investing foreign companies are export-oriented and less on satisfying domestic markets of the member receiving countries, when these do not have significant growth prospects of their domestic demand for goods.

\section{Problem Solution}

Technological transfer is a transfer of knowledge which is necessary to manufacture a product, application process or the provision of a service and is not limited to transactions involving the mere sale or lease single properties but rather to: transfer, sale or licensing of all forms of industrial property, communication skills and technical expertise (feasibility studies, engineering formulas of basic or detailed); specification and equipment for training services provided by the advisory staff and management and staff training; communication of information technology to acquire and operate machinery and intermediate goods. Most developing countries follow in succession a set of sequences in the process of technological diffusion that begins with the importation of standardized technologies, imitation, adaptation, transformation, and finally, the export of intermediate technology. However, when agreements with foreign partners, a fear may arise for business guests that rely exclusively on the key skills developed partner. This strong position may decide to take a financial advantage and capture the bulk of the value created by the alliance. These divergent interests may hinder the effects that could derive from this interaction.

To mitigate this threat, therefore, the host country must develop technological capability, which includes all the skills necessary for the proper functioning of industries, adaptation and appropriation of imported technologies. Accordingly, it is an environment conducive to technological innovation in the host country which is a key element of successful technology transfer. To know the scientific and technological infrastructure, the size of domestic markets, relations between different industrial sectors and institutional factors, social and national scientific institutions that form the basis of independent development. Investment in training, organizational change or recourse to technical assistance also helps to promote progressive learning at the level of production. Finally, it is necessary that the northern partner is ready and able to commit significant capital and/or technology, knowledge and make the necessary technological skills to help his partner in the host-countries with its task of learning and mastery of these technologies, based on success of the joint (Voiculescu, 2001, pp. 102-112).

\section{The Attractiveness of the Romanian Economy}

During the years after joining NATO, Romania has attracted FDI totalling 28.1 billion euros with an average of 5.6 billion euros per year. The FDI value was almost 3.5 times higher than that between 1991-2002, when Romania has attracted a FDI volume of 8.5 billion euros, equivalent with an average annual FDI of 708 
million euros. In 2008, after the European Union (EU) accession, Romania has had the highest growth rate, after the Czech Republic (see Figure 2).

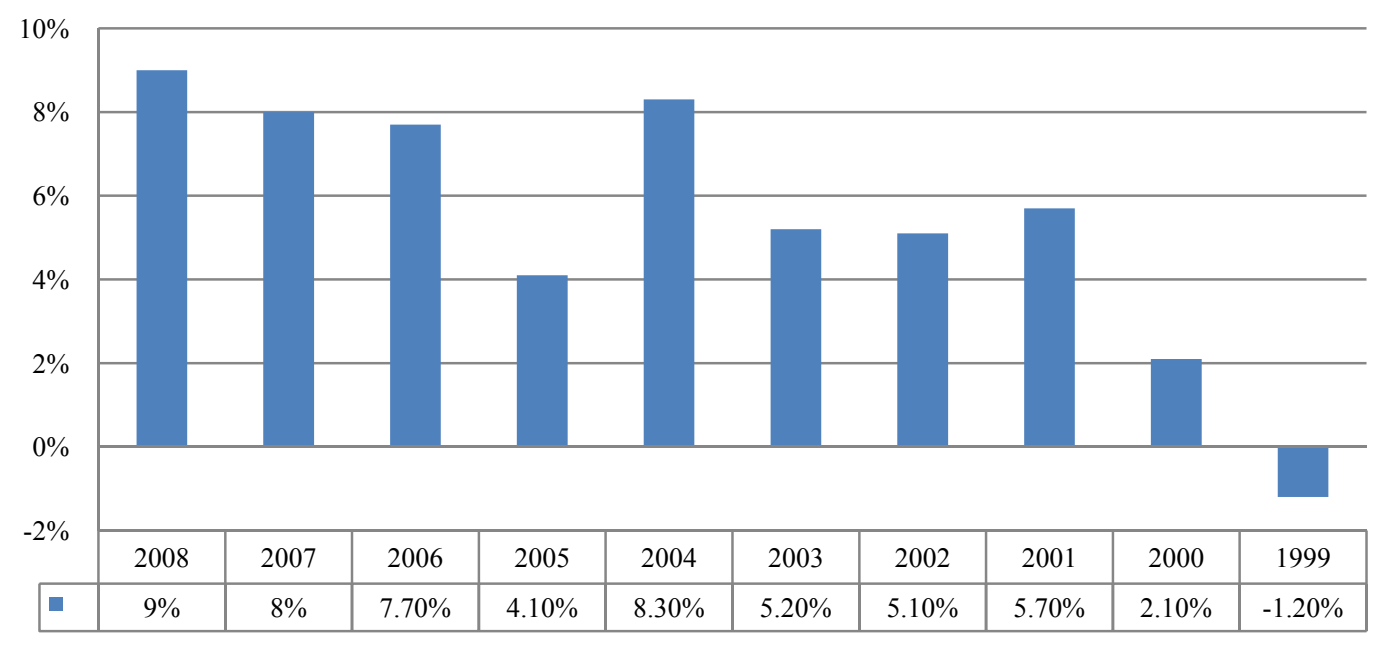

Figure 2. Growth rate of Romanian economy between 1999-2008. Source: www.bnr.ro.

If, during 2006, Romania ranked seventh in Europe in the top of countries attractive to foreign investors, in 2007, performance indicators have improved as a result of the full integration of Romania into the EU. Romania was considered in 2008, the most attractive economy for foreign investors ahead of countries like the Czech Republic, Poland, Hungary, which joined to EU in 2005 (see Figure 3).

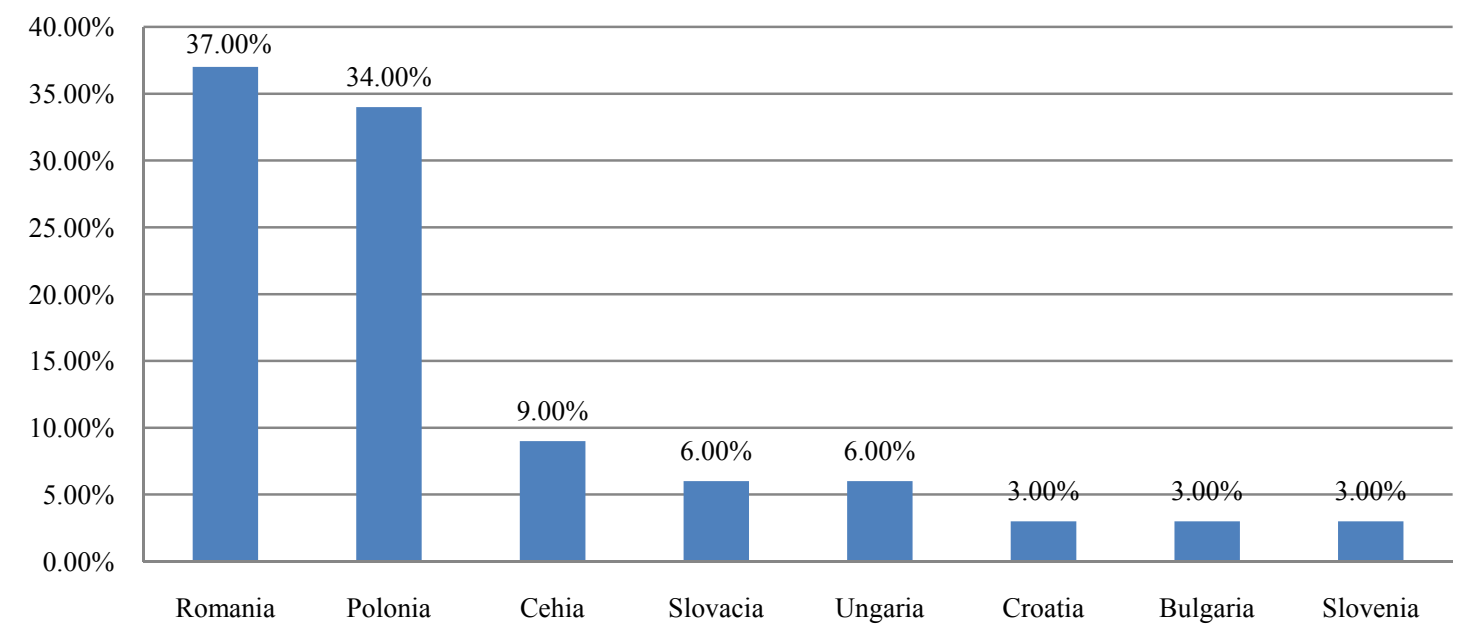

Figure 3. The most attractive ex-socialist countries of the European Union for the foreign investors in 2008. Source: www.bnr.ro.

\section{FDI Contribution of Romania to Assessing Its Ability of Technological Absorption}

In The statistical research report of the National Bank of Romania in cooperation with INSR publisher in the 1st quarter of 2008 is highlighted: a balance of FDI in 2007 to 42.770 million euros; participants to the social capital and reinvested profits of the FDI of 31.501 million euros (74\% of final FDI balance); total net credit received from foreign investors directly, including within the group, worth of 11.269 million euros which represented $26 \%$ of the final FDI balance (see Figure 4). 
During 2008 when the financial crisis began to be felt in the most countries of the world, the attractiveness of the Romanian economy for the foreign investors has remained strong and the FDI volume registered around 7.9 billion euro (see Figure 5).

In $2008,66.8 \%$ of the FDI shareholding was 3.517 million euros for the company developers, $32 \%$ for mergers and acquisitions, but only $1.2 \%$ for the Greenfield investments. In the 1 st semester of 2009 , the FDI volume registered 1.456 billion euros, down with $13.9 \%$, compared to the same period in 2008 , when they invested 1.690 billion euros (Neffati, Constantinescu, \& Chebira, 2009, pp. 160-165).

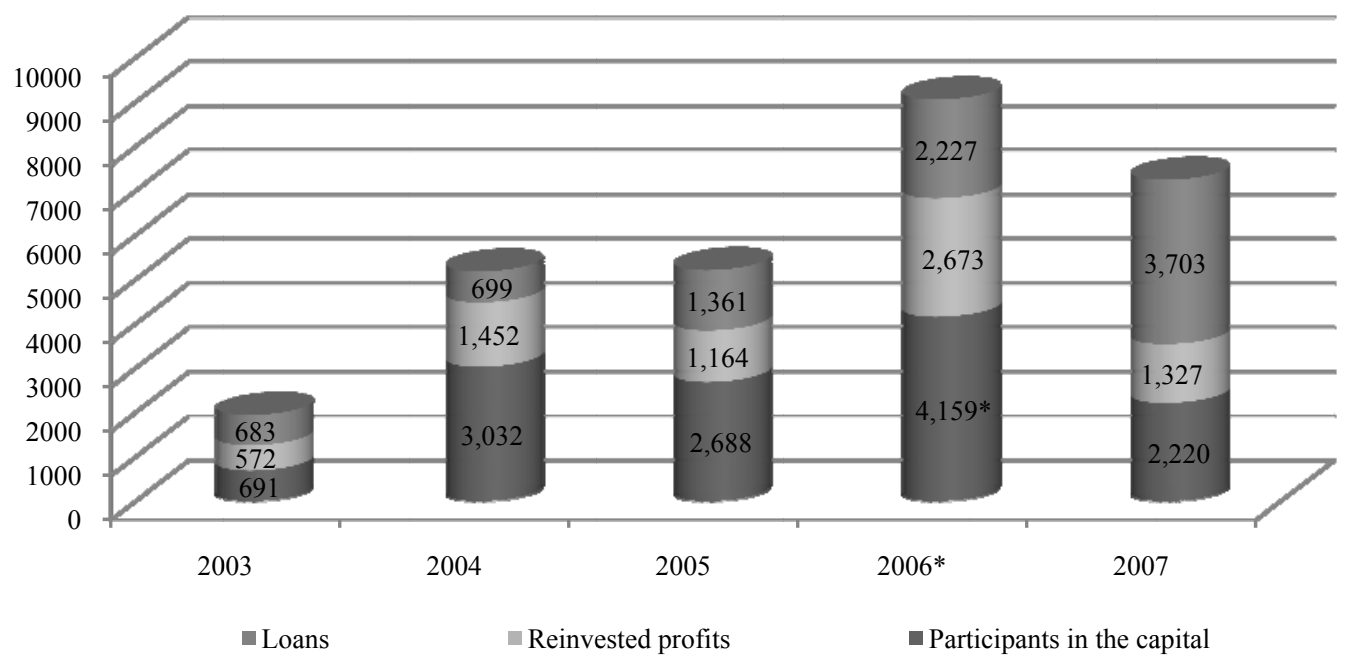

Figure 4. FDI volume of Romania on December 31, 2007. Source: www.bnr.ro.

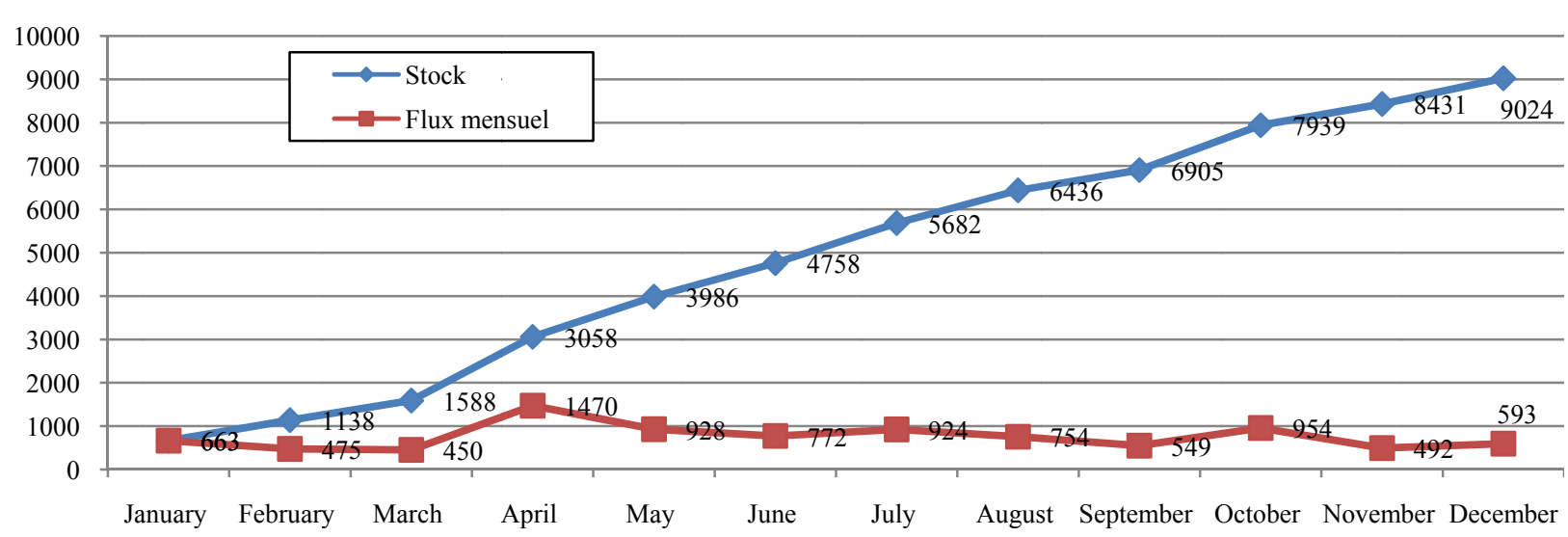

Figure 5. FDI stock and FDI monthly flux of Romania on December 31, 2008. Source: authors' calculation.

FDI location into Romanian economic sectors. The foreign investors orientation to Romanian economic branches (according to CAEN Rev. 2), located FDI, is primarily in the manufacturing industry ( $31.3 \%$ of total), the most attractive for FDI being metallurgy (6.9\% of total), food industry, beverages and tobacco (4.6\%), petroleum processing, chemicals, rubber and plastics (4.3\%), transportation means industry (4\%), cement, glass, ceramics (3.6\%). We still notice a low share compared to their potential for areas such as textile, clothing and leather industry which represents only 1.6\% of total FDI (see Figure 6 and Figure 7).

Other activities that have attracted significant for the foreign investers were: financial intermediation 
activity including banking, non-bank financial institutions and insurance (20.5\% of total FDI), construction and real estate (12.6\%), trade (12.4\%), and the ICT sector (6.7\%).

Top 5 countries of Romania, ranked by share of total FDI stock held on 31/12/2008 include: Austria (18.8\% of total FDI at the end of 2008 with a share down from $21.4 \%$ in 2007), Netherlands (17.2\%, up from $16.3 \%$ in 2007), Germany (15.4\%, up from $11.7 \%$ ), France $(8.8 \%$ ) which maintains their share in 2007 , and Italy (with a share up from $6.1 \%$ in 2007 to $7.3 \%$ ), replacing Greece in the hierarchy of the first 5 countries of origin of FDI in Romania. In the first half of 2009, FDI volume was of 1.456 billion euros, down $13.9 \%$, compared to the same period of 2008, when they invested 1.690 billion euros (Constantinescu, 2010).

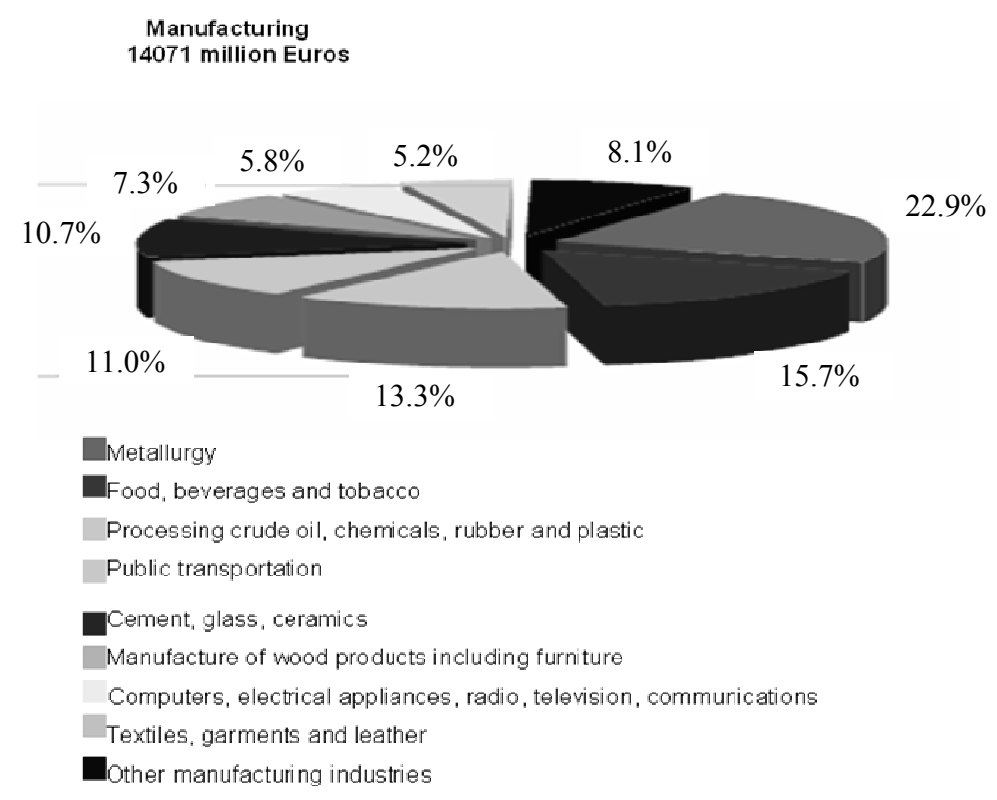

Figure 6. FDI distribution on the Romanian manufacturing industry in 2008.

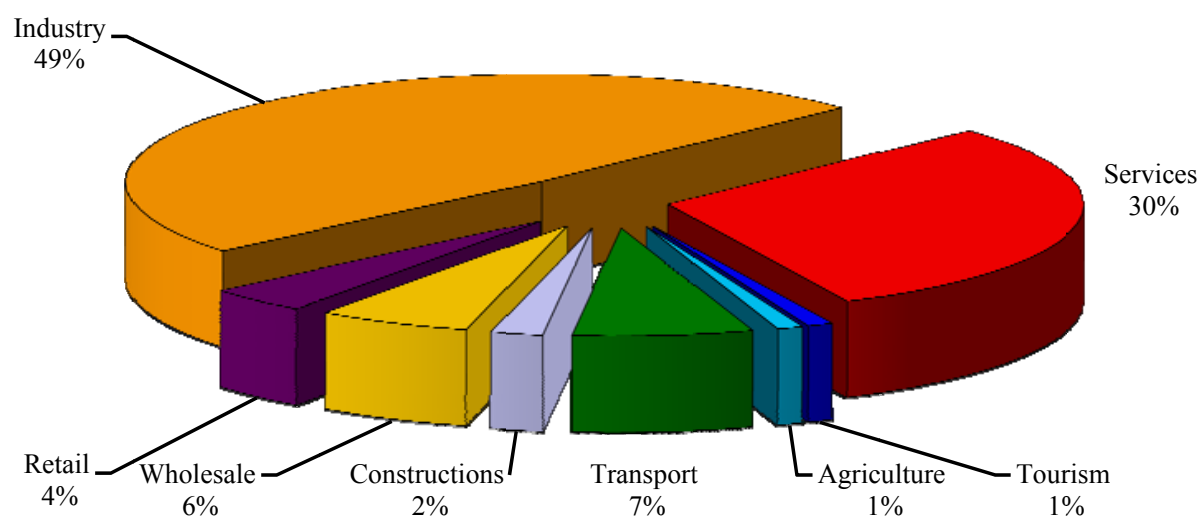

Figure 7. FDI distribution into Romanian economy of 2008. Source: www.bnr.ro.

\section{The FDI Enterprises' Contribution in Active Processing Regime to Romanian Exports After 2007}

Statistical research report conducted by the National Institute of Statistics and National Bank of Romania, published in the 1st quarter of 2008 is highlighted that FDI enterprises in retail and wholesale trade of Romania, have made $62.7 \%$ of exports (1.876 million euros) and respectively $47.7 \%$ (9.646 million euros) of Romania's 
imports in 2007 . The industry contributed $77.5 \%$ to Romanian exports during that the import represented $78.2 \%$ of total imports for the industrial sector (see Figure 8).

The domestic demand during 2008 has strengthened the position of the engine of economic growth. The segment responsible for this development was consumer demand, and the fastest growth rate since 1999 (13.7\%) (Constantinescu, 2010).

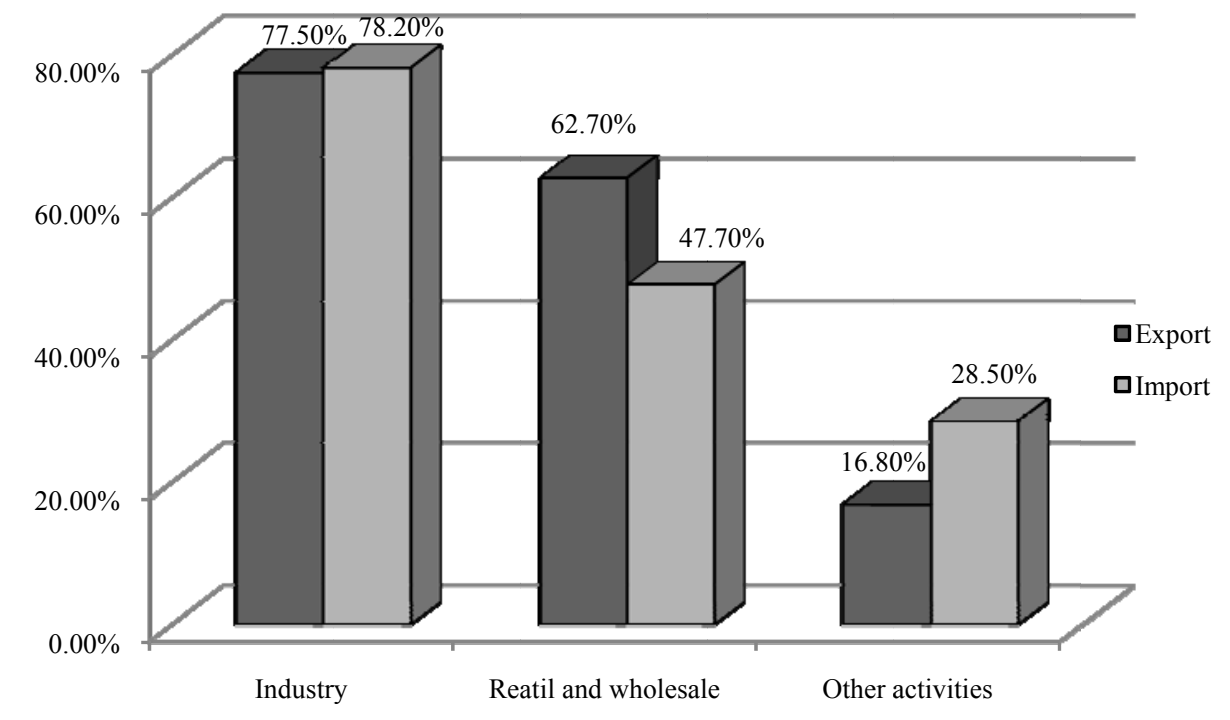

Figure 8. FDI contribution to the foreign trade of Romania in 2007. Source: www.bnr.ro \& www.insr.ro.

Gross fixed capital, the most dynamic segment of aggregate demand, saw a new moderation of pace (from $30 \%$ to $24.3 \%$ ), and the advance of exports representing goods and services was $17.4 \%$. The contribution of final consumption to Romania's GDP growth was supported mainly by the private sector $(+14.6 \%)$ and government consumption has registered a dynamic inferior only by $+4.9 \%$. Maintaining the downward trajectory of consumer demand, domestically and internationally, has resulted during the 1st quarter of 2009, for the first time since 2000, a decrease in real GDP, a restriction of the activity being visible in all sectors of the economy. The $(-6.2 \%)$ decline was more severe than anticipated in the projection of the B.N.R. benchmark made in March 2009 (-1.5\%). Compared with the last three months of 2008, final population consumption during the 1st semester of 2009 has accelerated about three times the decline to (-10.5\%). The main segment of responsibility is the procurement of goods and services in the commercial network (-13.4\%), due to the decrease of the financial resources of the population. The exports of goods and services dynamics saw a strong reversal sign, placing itself in the range of negative values (-19.6\%) for the first time since 1999 (Constantinescu, 2010).

The evolution of the net external demand partially compensated the decline in domestic absorption with a positive contribution to annual GDP growth, registering a significant increase compared to the 4th quarter of 2008 (from $4.3 \%$ to $9.7 \%$ ).

The result was due to the triple speed of adjustment of the volume of the imports of goods and services to $(-31.4 \%)$, due to, reducing domestic demand for consumption of intermediate goods for manufacturing export 
production and the contrary development of the exchange rate of the Romanian currency ${ }^{1}$. The main negative pulse upon the dynamics of imports was generated by the adjustment of domestic demand of vehicles, the purchase volume on foreign markets going down to less than one third in the 1st quarter of 2009 compared to the same period of 2008 (Constantinescu, 2010).

The contribution of the foreign direct investment enterprises into active proccessing regim to Romania trade balance represents $73 \%$ of exports (see Figure 9 and Figure 10) and $62.6 \%$ for the imports (see Figure 11 and Figure 12).

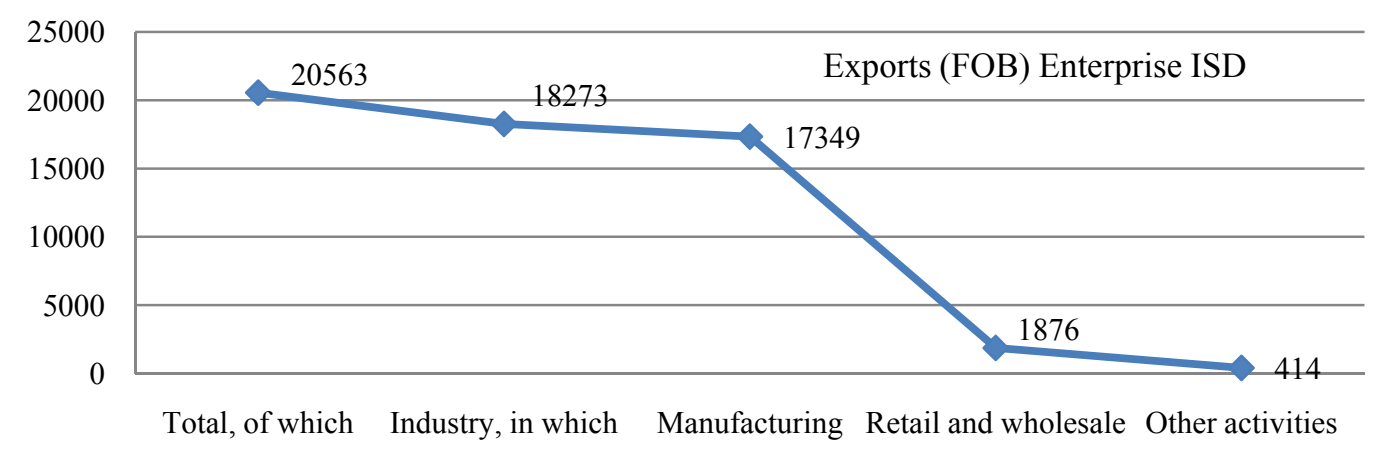

Figure 9. Romanian export trend (FOB value) in 2008 maded by FDI enterprises. Souce: authors' calculation.

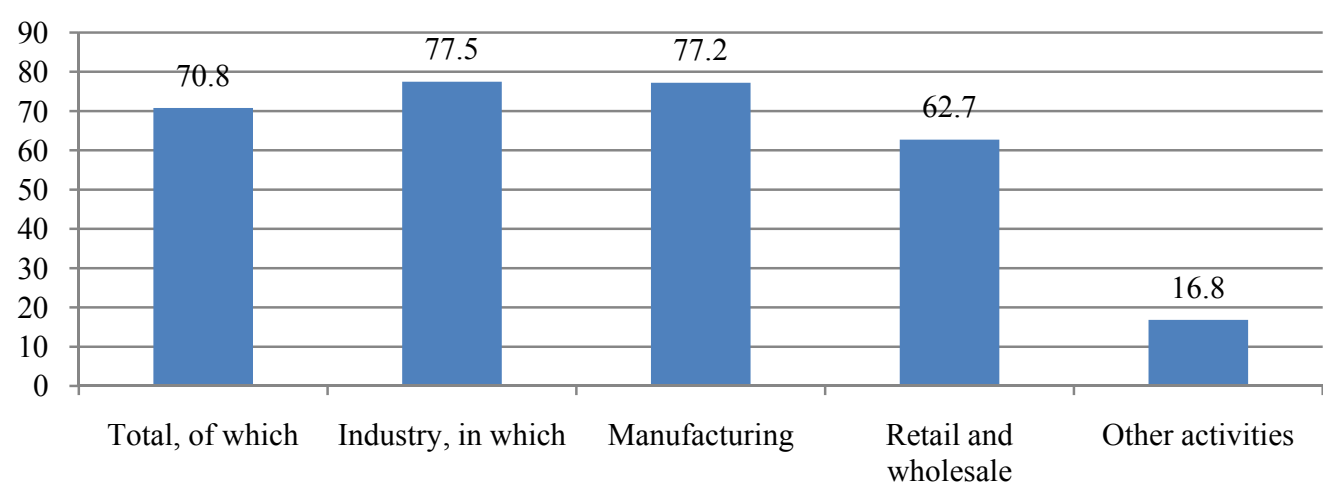

Figure 10. Romanian export volume (FOB value) in 2008 maded by FDI. Source: authors' calculation.

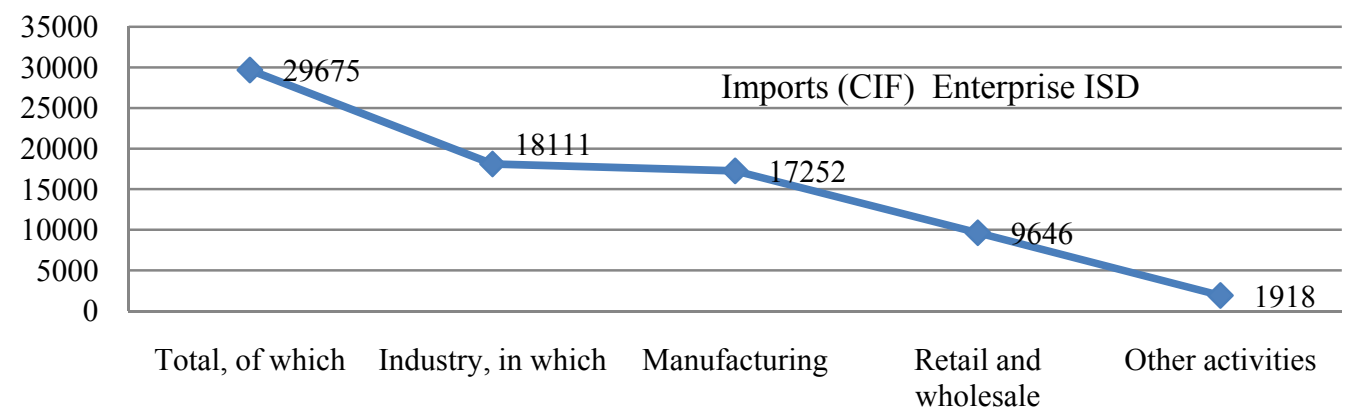

Figure 11. Romanian import trend (CIF value) in 2008 maded by FDI. Source: authors' calculation.

\footnotetext{
${ }^{1}$ Romania currency named "LEU" and it's abreviated as RON.
} 


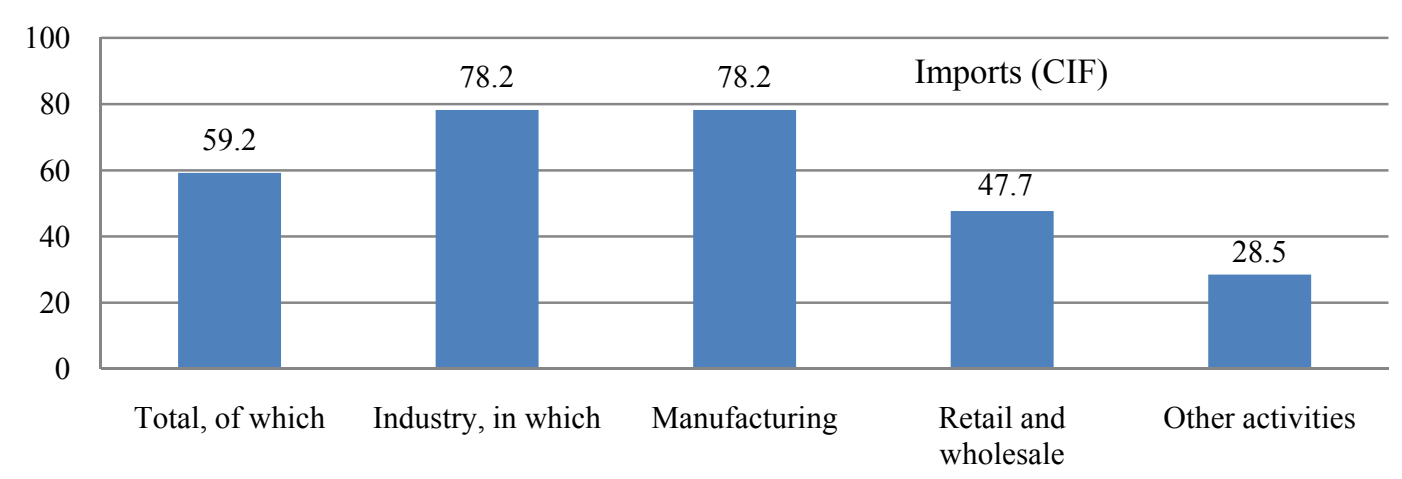

Figure 12. Romanian import volume (CIF value) in 2008 maded by FDI. Source: authors' calculation.

After the European Union accession, Romania has continuously increased their technological absorption capacity (see Table 1).

Table 1

FDI Flow Evolution During 2007-2008

\begin{tabular}{lcrrrrrrrrrrr}
\hline 2008 & Jan. & Feb. & Mar. & Apr. & May & June & July & Aug. & Sept. & Oct. & Nov. & Dec. \\
\hline Stock & 663 & 1,138 & 1,588 & 3,058 & 3,986 & 4,758 & 5,682 & 6,436 & 6,985 & 7,939 & 8,431 & 9,024 \\
Monthly flow & 663 & 475 & 450 & 1,470 & 928 & 772 & 924 & 754 & 549 & 954 & 492 & 593 \\
\hline 2007 & Jan. & Feb. & \multicolumn{1}{c}{ Mar. } & Apr. & May & June & July & Aug. & Sept. & Oct. & Nov. & Dec. \\
\hline Stock & 517 & 1,106 & 1,890 & 2,242 & 2,826 & 3,550 & 4,411 & 4,881 & 5,896 & 6,687 & 7,070 & 7,250 \\
Monthly flow & 517 & 589 & 784 & 352 & 584 & 724 & 861 & 470 & 1,015 & 791 & 383 & 180 \\
\hline
\end{tabular}

Notes. Source: www.bnr.ro; www.insr.ro; www.aris.ro.

During the first half of 2009, the FDI volume was 1.456 billion euro down $13.9 \%$, compared to the same period of the 2008, when it's invested 1.690 billion euros.

Despite the decline in imports and exports, the Romania trade deficit remains in the top of the EU countries. Thus, after the first seven months of 2009, Romania was placed to the 6th position among EU countries after the trade deficit volume, which stood at 5.1 billion euros, according to Eurostat Data. Trade deficit of our country still remains in the top of EU, even if it was reduced by $61.4 \%$ during January-July 2009 compared to same period in 2008. In 2009, Romania's economy shrinks 1.5\% in Q4 over Q3, fails to escape recession (Constantinescu, 2010).

\section{Conclusions}

The Romania's gross domestic product (GDP) compressed 1.5 percent in the last quarter of 2009 versus the previous quarter, while on the entire year, the economy reduced 7.2 percent over 2008, according to the preliminary data published by the National Institute in Statistics of Romania. Thus, Romania failed to escape recession for the 6th quarter in a row, despite estimates. The analysts polled by news in anticipated Romania's economy stepped out of recession in the 4th quarter of 2009, with an advance of 0.1-0.6 percent on the previous quarter, sustained by the industry's recovery, as constructions continue to have a negative contribution.

(1) Compared to the same period of 2008, the Romanian economy reduced 6.6 percent in the 4th quarter 2009, while on the whole, it stood 7.2 percent below the level of 2008. Compared to the 4th quarter of 2008 , 
Romania had during October-December 2009 the fourth drop of GDP in the European Union, of 6.6\%. Only the Baltic countries were before it. Thus, Latvia's economy contracted by $17.9 \%$, that of Lithuania, with $13 \%$ and Estonia with 9.4\%. Bulgaria had the fifth rate of decline of the economy compared to the 4th quarter of 2008 , by $6.2 \%$.

Throughout the whole European Union, the decrease during the 4th quarter of 2009 was $2.3 \%$ and the one in the euro area by $2.1 \%$, according to European Statistics Office. Eurostat also showed that the economy of the United States grew with $0.1 \%$ compared to the same quarter of 2008 and with $1.4 \%$ compared to the 3 rd quarter of 2009.

(2) Main growth engine of the Romanian economy in the coming period is the net exports. Domestic demand will come back in the following period. Net exports (the difference between imports and exports of Romania) had a negative contribution to GDP, the economy being based on imports, but the gap was reduced drastically due to economic crisis.

The first engine of the economic growth will be that of net exports. Manufacturing industry, which provides a lot of the exports, shows that the system already has ignited and it's only a matter of wise withdrawal of the stimuli in countries outside Romania.

The second engine will be the domestic demand, especially the consumption. The consumption in Romania has had, during the recent years, the largest share in GDP (aprox. 75\%), and now the economic recovery depends on resuming consumption, on sustainable basis. The net export and industry remained the main factors that will lead to the recovery of the GDP, but, on the other side, the consumption and investments remained weak considering that both retail sales and imports have declined in the last quarter of 2009.

The first half of 2010 might still look like further recession due to the fact that the minus $6.6 \%$ figure in the 4th quarter of 2009 shows that the period in which the financial crisis affects Romania is longer than the initial estimate of our policymakers and, as shown by the National Bank of Romania forecast it remains to be seen if the economy's advance during 2010 year will be of $1 \%$ or will possibly reach $3 \%$. Romania faces a significant economic slowdown due to the decline in exports, reduction of construction activity and decrease in the level of funding.

Although the payments balance deficit decreased down to -5,168 million euros, following the decrease of the import and export activity, the budget deficit of Romania increased in 2009 compared to 2008 with $48 \%$ in terms of a external debt of Romania to the International Monetary Fund and other international financial institutions. Romania has registered a gradual increase in current account deficit and capital account balance of payments, whose weight in GDP grew by $3.1 \%$ in 2002 to the very high levels, $12.8 \%$ of GDP in 2007. The International Investment Position of the Romania has deterirated significantly from (-26.9\%) in 2000 to $(-61.9 \%)$ of GDP in 2009.

(3) The Romanian National Prognose Commettee believes that Romania could come out of crisis during the 1st quarter of 2011. The ING Bank specialists afirm that a U-shaped recovery isn't a bad thing, as long as the appropriate economic measures are quickly implemented so as to give the start of a cycle of the sustainable economic growth on the medium term.

(4) In our opinion, Romania needs to think and implement "a project-resources vision". This "project-resources" doesn't mean one type of action should be the focus point of a chain "upstream" of 
economic, technical and social actions that allows it to happen. It must also be the starting point of a pathway "downstream" implementation of the development actions generated by the new opportunities offered to Romanian economy.

This "systemic" development by "project-resource vectors" brings a positive response to the question: "How do it together".

However, it requires more "professional" in public deliberations, fixing issues, the consistent application of models, the steering action.

The most as such measures was included in the agreement negotieted by Romania with the International Monetary Fund and the European Union also. Romania's with drawal from the crisis is very much dependent on what happens in the European Union countries and other countries of the world. Not so much the economic growth in these countries matters, as restoring confidence.

If confidence will be restored in to the developed countries on the planet, then, Romania will be one beneficiary, also.

\section{References}

Constantinescu, L. M. (2010). The financial crise effects to foreign direct investments portofolio from Romania. Unpublished paper presented to the 26th international colloque of Tiers Monde Association whit the theme Crises et soutenabilité du developpment, University of Strasburg, French, June 2010.

Dobrescu, E. (2008, February 13). The foreign direct investment cavalcade in Romania/Cavalcada investițiilor străine in România. Financial Newspaper.

Dumitru, I. (2005). Strategic marketing. A globalization approach/Marketing strategic. O abordare din perspectiva globalizării, Publishing House Uranus, Bucharest

Neffati, M., Constantinescu, L. M., \& Chebira, B. A. (2009). A comparative analisys of the competitiveness to Euro-Mediterranean area. Presented paper to the 56th International Association of Francophone Economists Congress whith the theme Compétitivité, solidarité et croissance économique mondialisée, Târgovişte, Romania, May, 2009. Published in the review Les Annales de l'université Valahia, section: Sciences économiques, No.26/2009, Publishing House Bibliotheca, Targoviste, pp.147-169 (http://journals.Indexcopernicus.com/karta.php ?action=masterlist\&id=1740 ).

Voiculescu, D. (2001). Competion and competitiveness/competiție şi competitivitate. Bucharest:Publishing House Uranus.

Voinea, L. (2007). Transnational corporations and global capitalism/corporațiile transnaționale şi capitalismul global. Iaşi: Polirom Publishing House Polirom. 